\section{Effect of Saline Irrigation Water on Antioxidants in Three Hydroponically Grown Leafy Vegetables: Diplotaxis tenuifolia, Eruca sativa, and Lepidium sativum}

\author{
Jeffrey M. Hamilton ${ }^{1,2}$ \\ Arid Land Resource Sciences, CEAC, University of Arizona, 1951 E. Roger \\ Road, Tucson, AZ 85719
}

\section{Jorge M. Fonseca \\ Department of Plant Science, Yuma Agricultural Center, University of Arizona, 6425 W. 8th Street, Yuma, AZ 85364}

Additional index words. Arugula, controlled environment agriculture, greenhouse, total phenolics, postharvest, salinity, ascorbic acid

\begin{abstract}
Our study evaluated changes in nutritional content of leafy vegetables at harvest and during postharvest in response to nutrient solutions of increasing salinity using a recirculating ebb and flow irrigation system within a controlled environment (CE). Two antioxidants, ascorbic acid (AsA) and total phenolics (TP), were used as proxies for nutrition as determined by the 2,6-dichloroindolphenol titrimetric and the Folin-Ciocalteu methods, respectively. Two arugulas, Diplotaxis tenuifolia (L.) DC cv. Sylvetta and Eruca sativa (P. Mill.) Thell. cv. Astro, and a garden cress, Lepidium sativum L. cv. Presto, were grown with five salinity levels ranging from 1.5 to $9.5 \mathrm{dS} \cdot \mathrm{m}^{-1}$ electrical conductivity (EC) during two trials. We observed no difference in TP at harvest in response to salinity treatments in Trial 1 for all species collectively evaluated; however, during Trial 2, the TP at harvest responded to salinity treatments. In contrast, we observed a response in AsA at harvest to salinity treatments during both trials. The response of both TP and AsA to treatments was characterized by variability, both increases and decreases, when contrasting species and trials. We concluded that the variability in the nutritional content of the specific crucifers evaluated might reflect both individual species responses and the modest CE microclimate changes we recorded between trials. In addition, our research suggests that salinity levels greater that an EC of $9.5 \mathrm{dS} \cdot \mathrm{m}^{-1}$ may be required to define the salinity tolerance of these specific crucifers within a $\mathrm{CE}$.
\end{abstract}

Increased consumption of fruits and vegetables is associated with a lower incidence of numerous cancers and cardiovascular diseases (Surh, 2003). The daily intake of plant phenolics and vitamin $\mathrm{C}$, both known for their high antioxidant capacity, is attributed primarily to the consumption of fruits and vegetables (Kim and Lee, 2004; Rice-Evans et al., 1997). Plants grown under stress (e.g., aridity) produce quantitatively more antioxidant compounds (Reddy et al., 2004). Given that the diverse Brassicaceae family (crucifers) is reported to

Received for publication 18 Nov. 2009. Accepted for publication $10 \mathrm{Feb} .2010$.

This research was funded in part by the USDA funded Arizona Department of Agriculture Specialty Crop Grant Program.

C. Kubota, G. Giacomelli, and M. Kroggel, University of Arizona's Controlled Environment Agricultural Center, provided greenhouse, laboratory facilities, and technical suggestions.

${ }^{1}$ Current address: 6719 North Quartzite Canyon Place, Tucson, AZ 85718.

${ }^{2}$ To whom reprint requests should be addressed; e-mail jeffreymuirhamilton@me.com. supports the observation that plants grown under conditions of stress have higher leaf phenolic concentrations, be that stressor highlight (Tattini et al., 2004) or salinity (Tassoni et al., 2008). Thus, our research would contribute to understanding the effect of selected levels of salinity on plant-derived dietary antioxidants such as vitamin C (Smirnoff, 2000) and polyphenols (Podsedek, 2007; Rice-Evans et al., 1997) in three neglected specialty crucifers (Nuez and Hernández Bermejo, 1994). This would provide value (i.e., a greater diversity of vegetables with known nutritional values) for consumers and create additional opportunity for producers (Bachmann, 2002) with opportunity defined as knowledge of the response of high-value specialty crops to irrigation water of known salinity (Shannon and Grieve, 1999). A demonstration that vegetable nutrition can be maintained in an ebb and flow irrigation (EFI) water recycling system within a controlled environment would suggest the value of recycling irrigation water. In addition, EFI systems limit water use and environmental pollution associated with nutrient solution runoff (Shalhevet, 1994). Available information is limited on the effect of EFI systems on vegetable crops quality in general (Rouphael and Colla, 2005) and especially on the crucifers in our study (Nicola et al., 2007). Specialty leafy vegetables (Bachmann, 2002), with reported nutritional benefits, offer regional growers a price and marketing advantage given that consumers are increasingly aware of nutritional food values for which they are willing to pay a premium (Winter and Davis, 2007).

Of the crops selected for this study, the arugula $E$. sativa is a common component in specialty salad mixes; however, the wild arugula $D$. tenuifolia, although common in the Mediterranean region (Di Venere et al., 2000; Martínez-Laborde, 1997) and discussed in high-end cooking forums, is rare in markets within the United States. The least evaluated crucifer is a garden cress, L. sativum; it is uncommon in the United States with little reported nutritional data (Nuez and Hernández Bermejo, 1994). Results from our field trials with arugula (Hamilton, 2010) revealed higher antioxidant values than in commercially available arugula, suggesting that agronomic factors characteristic of the arid Southwest (e.g., salinity level in the water or high solar radiation) may contribute to the higher values (Table 1). It was previously reported that Romaine and iceberg lettuce (Lactuca sativa L.) grown in the southwestern United States showed an improvement in green color and an increased accumulation of total phenolics (TP) with high salinity in the water (Fonseca et al., 2009; Kim et al., 2008).

The response of plant TP to light has been studied in field-cultivated spinach (Spinacia oleracea L.) (Bergquist et al., 2007b) and lettuce (Hamilton, 2010) as well as to changing levels of greenhouse irradiance in a medicinal herb (Labisia pumila Benth.) (Jaafer et al., 2008); however, abiotic factor influences on TP in crucifers are usually associated 
with field studies (Di Venere et al., 2000; Martínez-Sánchez et al., 2007). Like with phenolics, vitamin $\mathrm{C}$ has been reported to increase in cherry tomato (Lycopersicon esculentum Mill.) in response to increasing salinities ranging from electrical conductivity (EC) 1.0 to $6.0 \mathrm{dS} \cdot \mathrm{m}^{-1}$ (Serio et al., 2004); vitamin $\mathrm{C}$ declines in Pak Choi (Brassica rapa L.) in response to salinity above EC $9.5 \mathrm{dS} \cdot \mathrm{m}^{-1}$ (Mahmud et al., 1999).

Our objective was to evaluate the effect of water stress on two antioxidants in three specialty leafy vegetables imposed by an increasing regime of salinity in the irrigation water. A secondary goal was to determine if a controlled environment (CE) facility coupled with an EFI system could be implemented to efficiently obtain added value [e.g., higher levels of TP and ascorbic acid (AsA) than currently published] while recycling a nutrient solution during the production cycle. To the best of our knowledge, information concerning the specific effects of a range of salinity treatments on the nutritional status of our selected crucifers is limited. Those unreported salinity effects in association with the upward trend in CE production, particularly in arid water-limited regions, suggest our research should have value for producers and consumers.

\section{Materials and Methods}

Plant materials and growth environment. D. tenuifolia cv. Sylvetta, E. sativa cv. Astro, and L. sativum cv. Presto (Johnny's Selected Seeds, Winslow, ME) were sown in a $40 \%$ perlite, $40 \%$ vermiculite, and $20 \%$ peatmoss medium (as measured by volume) within $72-$ cell germination trays (TLC plug flats; International Greenhouse, Danville, IL). The tray cell volume was $57 \mathrm{~cm}^{3}$. Once seeds were sown, cells were then capped with a thin layer of vermiculite, misted with tap water, and then seed trays were covered with two layers of a floating row cover (Agribon Ag-30; Polymer Group, Inc., Charlotte, NC) and placed within EFI tables in a climate-controlled greenhouse. A 50\% knitted polypropylene shadecloth (Green-Tek, Inc., Edgerton, WI) was placed $2.5 \mathrm{~m}$ above tables. Seeds were subirrigated three times every $24 \mathrm{~h}$ for $5 \mathrm{~min}$ with water $\left(\mathrm{pH} 7.8\right.$; EC $\left.0.40 \mathrm{dS} \cdot \mathrm{m}^{-1}\right)$. The oxidation-reduction potential (ORP) status (Suslow, 2004) of our water systems was adjusted with a hydrogen peroxide-based fungicide (ZeroTol; BioSafe Systems, East Hartford, CT) to an ORP value of $300 \mathrm{mV}$ (pH 6.5, EC $0.40 \mathrm{dS} \cdot \mathrm{m}^{-1}$ ).

Treatments. The five salinity treatments included the following EC values: 1.5 (control), 3.5, 5.5, 7.5, and $9.5 \mathrm{dS} \cdot \mathrm{m}^{-1}$. Five, 8, and $10 \mathrm{~d}$ after the respective seed germination of E. sativa, L. sativum, and D. tenuifolia, seedlings were fertigated with a half-strength nutrient solution (EC $0.75 \mathrm{dS} \cdot \mathrm{m}^{-1} ; \mathrm{pH}$ 6.5) and row covers were removed. Full-strength nutrient solutions (EC $1.5 \mathrm{dS} \cdot \mathrm{m}^{-1}$; $\mathrm{pH}$ 6.5) were applied after $7 \mathrm{~d}$ of half-strength nutrient solution. Fifteen d after germination, treatments were initiated by incremental in- corporation of a saline solution into nutrient solution tanks until the first target EC of 3.5 $\mathrm{dS} \cdot \mathrm{m}^{-1}$ was achieved with all treatment plants with the exception of the control that was retained at an EC of $1.5 \mathrm{dS} \cdot \mathrm{m}^{-1}$. Separate tables and nutrient solution tanks were maintained for each of the five treatments. After $3 \mathrm{~d}$ at the lowest salinity treatment, all plants, except the lowest salinity treatment plants, were moved to the next higher salinity treatment. This incremental increase to higher salinity treatments was repeated until three replications of each cultivar were established within each of the five tables. All plants were maintained in target nutrient solutions until the highest salinity treatments plants received the EC of $9.5 \mathrm{dS} \cdot \mathrm{m}^{-1}$ treatment for 2 weeks. Trays were positioned in tables to avoid trayto-tray contact and rotated within a table every third day. Treatments were assigned to tables randomly in both Trials 1 and 2 . The hydrogen peroxide-based fungicide concentration, within nutrient solution tanks, was maintained within an ORP range of 200 to $350 \mathrm{mV}$ and a $\mathrm{pH}$ range of 6.0 to 7.0 .

Nutrient and saline solutions. A concentrated stock nutrient solution was prepared in 19.0-L containers and was comprised of the following elements in $\mathrm{mg} \cdot \mathrm{L}^{-1}: 30.0$ nitrogen, 5.0 phosphorus, 20.0 potassium, 22.2 calcium, 8.6 chlorine, 7.8 sulfur, 6.0 magnesium, 0.4 iron, 0.1 copper, 0.09 zinc, 0.07 manganese, and 0.001 molybdenum. Aliquots of the stock nutrient solution were added to all 170-L tanks until the control EC of $1.5 \mathrm{dS} \cdot \mathrm{m}^{-1}$ was attained. Water lost from tanks as a result of evapotranspiration was replaced with nutrient solution diluted to the EC of that specific treatment tank with an equal and simultaneous replenishment to all treatment tanks. A concentrated stock saline solution was prepared with $200 \mathrm{~g} \mathrm{NaCl}$ and $200 \mathrm{~g} \mathrm{CaCl}_{2}$ per liter of water. Aliquots sufficient to attain target salinities were determined by measuring the EC of the solution within tanks.

Greenhouse microenvironment. The plants were cultivated in a greenhouse at the Controlled Environment Agricultural Center, University of Arizona (Table 2). Temperature and relative humidity measures for each trial represent means derived from eight individual stations with data collected every $15 \mathrm{~min}$. Within the greenhouse, solar radiation was measured from 0645 to $1900 \mathrm{HR}$ and was recorded at canopy level (Table 2).

Measurements. Within the greenhouse, EC and $\mathrm{pH}$ were measured using handheld $\mathrm{EC}$ and pH meters (ECTestr high, PhTestr1; Oakton Instruments, Inc., Vernon Hills, IL); ORP was measured using a handheld ORP and temperature meter (HI 98121; Hanna Instruments, Woonsocket, RI). Air temperature and relative humidity were measured using an integratedtype transmitter (Vaisala Humiter 50-Y, Helsinki, Finland) mounted within an aspirating polyvinyl chloride housing positioned $0.25 \mathrm{~m}$ above the center of each treatment table. Media temperature was measured using radiation-shielded $0.5 \mathrm{~mm}$ Type-T thermocouple wire placed within three media trays in two treatment tables. Photosynthetically active radiation $(P A R), 400$ to $700 \mathrm{~nm}$ waveband, was monitored with a light sensor (LI-COR LI-190 Quantum sensor; Lincoln, NE) centrally positioned between four treatment tables at canopy height. All devices were connected

Table 1. Tucson, AZ, 2008, climate data outside a controlled environment (OCE), reported as in daily averages and ranges for solar radiation $(\mathrm{SR})$, temperature $\left({ }^{\circ} \mathrm{C}\right)$, and relative humidity $(\mathrm{RH})$ during Trial 1 (TI) and Trial 2 (TII). ${ }^{\mathrm{z}}$

\begin{tabular}{lcccc}
\hline Tucson, AZ; $713 \mathrm{~m}$ & & & & \\
$\left(\right.$ long. 32 $16^{\prime} 49^{\prime \prime} \mathrm{N} ;$ lat. $\left.110^{\circ} 56^{\prime} 45^{\prime \prime} \mathrm{W}\right)$ & March TI & April TI & May TII & June TII \\
\hline OCE SR Langleys/d & 506 & 647 & 668 & 688 \\
OCE SR Range Langleys/d & $274-606$ & $398-701$ & $316-760$ & $400-744$ \\
OCE SR $\mathrm{kW} \cdot \mathrm{h} \cdot \mathrm{m}^{-2} \cdot \mathrm{d}^{-1}$ & 5.87 & 7.50 & 7.74 & 7.98 \\
OCE SR $>0.10 \mathrm{~kW} \cdot \mathrm{h}^{-2} \cdot \mathrm{m}^{-1} \cdot \mathrm{d}^{-1 \mathrm{y}}$ & 9.8 & 10.0 & 11.0 & 11.7 \\
OCE SR mol $\cdot \mathrm{m}^{-2} \cdot \mathrm{d}^{-1}$ & 44.1 & 56.4 & 58.2 & 59.9 \\
OCE mean $\left({ }^{\circ} \mathrm{C}\right)$ & 14.8 & 19.3 & 22.7 & 29.9 \\
OCE range $\left({ }^{\circ} \mathrm{C}\right)$ & $-0.5-30.1$ & $2.3-35.2$ & $6.1-38.7$ & $11.8-42.3$ \\
OCE RH \% & 34.6 & 21.6 & 25.3 & 22.1 \\
OCE RH \% range & $4.5-100$ & $2.3-82.1$ & $2.3-90.6$ & $2.9-86.5$ \\
\hline
\end{tabular}

${ }^{z}$ Solar radiation data were measured in the 400- to $1100-\mathrm{nm}$ waveband range using a pyranometer (LICOR; Lincoln, NE) by the Arizona Meteorological Network, University of Arizona, Tucson, AZ. ${ }^{y}$ Number of hours per day of solar radiation greater than unit specified $(0.10)$.

Table 2. Tucson, AZ, 2008, climate within a controlled environment (CE). ${ }^{\mathrm{z}}$

\begin{tabular}{lcc}
\hline Tucson, AZ; $713 \mathrm{~m}$ & & May to June TII \\
$\left(\right.$ long. $32^{\circ} 16^{\prime} 49^{\prime \prime} \mathrm{N} ;$ lat. $\left.110^{\circ} 56^{\prime} 45^{\prime \prime} \mathrm{W}\right)$ & March to April TI & 846 \\
\hline$P A R \mu \mathrm{mol} \cdot \mathrm{m}^{-2} \cdot \mathrm{s}^{-1}$ & 1208 & 23.24 \\
$P A R$ mol $\cdot \mathrm{m}^{-2} \cdot \mathrm{d}^{-1}$ & 22.55 & $23.1 \pm 1.8$ \\
$\mathrm{CE}$ mean day $\left({ }^{\circ} \mathrm{C}\right)$ & $22.3 \pm 2.5$ & $17.6 \pm 3.0$ \\
$\mathrm{CE}$ mean night $\left({ }^{\circ} \mathrm{C}\right)$ & $19.5 \pm 0.6$ & $54.1 \pm 6.7$ \\
$\mathrm{CE}$ mean day $\mathrm{RH} \%$ & $37.4 \pm 9.9$ & $59.5 \pm 13.0$ \\
CE mean night $\mathrm{RH} \%$ & $32.9 \pm 5.4$ & \\
\hline
\end{tabular}

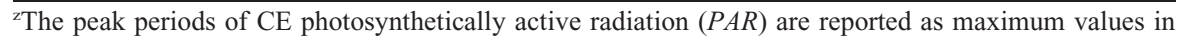
micromoles per square meter per second $\left(\mu \mathrm{mol} \cdot \mathrm{m}^{-2} \cdot \mathrm{s}^{-1}\right)$. Reported as daily-means $\pm \mathrm{SD}$ are: $P A R$ at canopy level as $\mathrm{mol} \cdot \mathrm{m}^{-2} \cdot \mathrm{d}^{-1}$, temperature $\left({ }^{\circ} \mathrm{C}\right)$, and relative humidity $(\mathrm{RH})$ during Trial 1 (TI) and Trial 2 (TII). The PAR was measured in the 400- to 700-nm waveband range (LI-COR LI-190 Quantum sensor; Lincoln, $\mathrm{NE})$, the unit of measurement is $\mu \mathrm{mol} \cdot \mathrm{m}^{-2} \cdot \mathrm{s}^{-1}$. 
to a datalogger (Campbell Scientific CR-23X Datalogger; Logan, UT). A spectrophotometer (Beckman Coulter DU-64, Fullerton, CA) was used for total phenolic measurements.

Harvest-postharvest storage. Crops were manually harvested in the greenhouse at 0800 HR with a sharp, stainless steel knife. Leaves were cut $2 \mathrm{~cm}$ above growth media, placed directly into 1.89 -L food storage containers (Glad plastic PP 5; Oakland, CA), weighed, and then transferred to a dark $12{ }^{\circ} \mathrm{C}$ walk-in cooler within $1 \mathrm{~h}$.

Total phenolic extraction and determination. For each replicate, $5 \mathrm{~g}$ of freshly harvested leaf tissue was chopped in a kitchen minichop (Braun MR430HC, Kronberg, Germany) for three 5-s pulses, mixed to a paste in a mortar with a pestle for $30 \mathrm{~s}$, and blended with $10 \mathrm{~mL}$ of $80 \%$ aqueous ethanol in $18-\mathrm{mL}$ tubes (Falcon; BD Biosciences, San Jose, CA). The mixture was shaken in a water bath in the dark for $12 \mathrm{~h}$ at $30^{\circ} \mathrm{C}$ and filtered through $\# 2$ filter paper (Whatman, Piscataway, NJ); the ethanolic supernatant was used for the determination of phenolic compounds. The total phenolic content was determined using FolinCiocalteu's reagent method as described by Singleton (Singleton et al., 1999). At $25^{\circ} \mathrm{C}, 50$ $\mu \mathrm{L}$ of the ethanolic extract was added to 350 $\mu \mathrm{L}$ of deionized water and $250 \mu \mathrm{L}$ of FolinCiocalteu's reagent. After $5 \mathrm{~min}, 1.0 \mathrm{~mL}$ of $10 \%$ aqueous $\mathrm{Na}_{2} \mathrm{CO}_{3}$ solution was added, the mixture was vortexed for $10 \mathrm{~s}$, then covered and incubated in the dark at $25^{\circ} \mathrm{C}$ for $120 \mathrm{~min}$. The incubated solution $(\approx 1.5 \mathrm{~mL})$ was transferred to microcuvettes. The absorbance was measured at $765 \mathrm{~nm}$; a standard curve was prepared using gallic acid (GA) (Merck, Darmstadt, Germany), and the absorbance was converted to the content and expressed in terms of $\mathrm{mg}$ GA-equivalent/100 $\mathrm{g}$ fresh weight of sample. Solutions and GA calibration standards were prepared as described by Waterhouse (Waterhouse, 2005); the calibration curve range was 20 to $200 \mu \mathrm{g} \cdot \mathrm{mL}^{-1}$.

Ascorbic acid extraction and determination. For each replicate, $2 \mathrm{~g}$ of fresh whole leaf tissue was placed in a freezer for 5 min within a covered mortar that has been stored in a $0{ }^{\circ} \mathrm{C}$ freezer. The tissue was then rapidly ground (less than $30 \mathrm{~s}$ ) with a $5 \mathrm{~mL}$ solution of ice-cold metaphosphoric acid and acetic acid (i.e., the extraction solution). The resultant extract slurry was filtered into glass culture tubes housed within an ice-water bath and the extract was then centrifuged for $10 \mathrm{~min}$ at $1000 \mathrm{~g}_{\mathrm{n}}$. The extraction solution was prepared by mixing 15 $\mathrm{g}$ of metaphosphoric acid pellets (33.5\%) in 40 $\mathrm{mL} \mathrm{HOAc}(99 \%)$ and $200 \mathrm{~mL} 0.3 \mathrm{~N} \mathrm{H}_{2} \mathrm{SO}_{4}$ diluted to $500 \mathrm{~mL}$ with deionized water, rapidly filtered into an amber glass bottle, and stored at $4{ }^{\circ} \mathrm{C}$ (AOAC, 1990). The ascorbic acid content was determined using a modified version of the 2,6-dichlorophenolindophenol (DCPIP) titrimetric method (AOAC, 1990). From this extraction, $1.5-\mathrm{mL}$ aliquots of the supernatant were pipetted into glass culture tubes; then a $0.025 \%$ DCPIP (Acros Organics, Geel, Belgium) solution was added dropwise to the extract until the almost colorless extract shifted to a rose-pink end point color, which persisted for at least $30 \mathrm{~s}$ The replicated titration with DCPIP was carried out rapidly to pounds, phenols, and sulfites (Albrecht and Schafer, 1990). The DCPIP solution was prepared by dissolving $50 \mathrm{mg}$ DCPIP in $50 \mathrm{~mL}$ deionized $\mathrm{H}_{2} \mathrm{O}$ containing $42 \mathrm{mg} \mathrm{NaHCO}_{3}$, shaken vigorously to dissolve, diluted to 200 $\mathrm{mL}$ in deionized $\mathrm{H}_{2} 0$, filtered into amber glass, and stored at $4{ }^{\circ} \mathrm{C}$ (AOAC, 1990). Three replicates of each standard and each treatment sample were titrated with the DCPIP solution. The mean values reported are expressed as milligrams of vitamin $\mathrm{C} / 100 \mathrm{~g}$ of fresh weight material. Calculations, solutions, and ascorbic acid calibration standards were prepared as described by AOAC (AOAC, 1990). The ascorbic acid content was calculated on the basis of the calibration curve of L-ascorbic acid (J.T. Baker, Phillipsburg, NJ); the calibration curve range was 20 to $240 \mu \mathrm{g} \cdot \mathrm{mL}^{-1}$.

Experimental design and statistics. Our completely randomized experimental design included three crucifer species subjected to five salinity treatments (EC range 1.5 to 9.5 $\mathrm{dS} \cdot \mathrm{m}^{-1}$ ). Plant leaf material was harvested from three randomly selected cells within the 72-cell trays for each of the three replicates and for all five treatments. The experiment was completed twice and all assays were repeated in triplicate; the results were expressed as means \pm sDs. Data for each dependent variable (AsA and TP) were subjected to minimize interference by sulphydryl com-

one-way analysis of variance (ANOVA). A factorial ANOVA was limited to the three species collective data at harvest. Independent of the ANOVA, results were tested by Levene's test for homogeneity of variances and if significant were analyzed using the Welch ANOVA. Homogeneous subsets were determined by Duncan's multiple range test. Relationships between treatments and the dependent variables were modeled by regression analysis. All statistical computations were carried out using a statistical software package (Version 16.0.2 for Mac; SPSS Inc., Chicago, IL), and differences were deemed significant at $P \leq 0.05$.

\section{Results}

Total phenolics. For all species collectively evaluated, we observed no difference in TP at harvest in response to salinity treatments in Trial 1. In contrast, during Trial 2, the TP at harvest responded to salinity treatments $(P \leq 0.05$; Table 3$)$. Species did have a significant effect on TP; however, only in Trial 1 was there an interaction between treatment and species on TP. Table 4 shows the variability of the at-harvest TP responses to salinity treatments when contrasting species and between trials. During both trials, there was not a consistent trend of increasing or declining TP in response to salinity. The TP responses $8 \mathrm{~d}$ postharvest $(8 \mathrm{DPH})$ to treatments

Table 3. Analysis of variance of the effects of salinity treatments and species and their interactions at harvest on total phenolics (TP) and ascorbic acid (AsA).

\begin{tabular}{lcccr}
\hline Source of variation & Trial 1 TPC & Trial 1 AsA & Trial 2 TPC & Trial 2 AsA \\
\hline Treatments (T) & NS & $* * *$ & $* * *$ & $* * *$ \\
Species $(\mathrm{S})$ & $* * *$ & $* * *$ & $* *$ & $* * *$ \\
$\mathrm{~T} \times \mathrm{S}$ & $* *$ & $*$ & NS & NS \\
\hline
\end{tabular}

NS $=$ nonsignificant $; * * *$, and $* * *$ represent significance at $0.01<P<0.05,0.001<P<0.01$, and $P<0.001$ levels, respectively.

Table 4. Analysis of variance and regression analysis of harvest total phenolic (TP) responses to five salinity treatments in three crucifers in two trials.

\begin{tabular}{|c|c|c|c|c|}
\hline \multirow{2}{*}{\multicolumn{2}{|c|}{ Treatments }} & Eruca sativa & Diplotaxis tenuifolia & Lepidium sativum \\
\hline & & TP & $\mathrm{TP}$ & TP \\
\hline \multirow[t]{8}{*}{ Trial 1} & $\mathrm{EC}-1.5$ & $121.35 \pm 9.9 \mathrm{a}$ & $95.76 \pm 2.5$ & $94.13 \pm 10.3$ \\
\hline & EC-3.5 & $105.97 \pm 16.1 \mathrm{ab}$ & $81.87 \pm 5.0$ & $84.91 \pm 10.4$ \\
\hline & EC-5.5 & $111.51 \pm 6.8 \mathrm{a}$ & $89.10 \pm 4.0$ & $105.54 \pm 10.8$ \\
\hline & EC-7.5 & $125.64 \pm 9.5 \mathrm{a}$ & $80.64 \pm 4.0$ & $98.67 \pm 3.1$ \\
\hline & EC-9.5 & $88.93 \pm 6.4 \mathrm{~b}$ & $92.57 \pm 12.0$ & $96.94 \pm 12.5$ \\
\hline & ANOVA $^{z}$ & $*$ & NS & NS \\
\hline & Welch-F ${ }^{y}$ & NA & NA & NA \\
\hline & Regression $^{\mathrm{x}}$ & NS & NS & NS \\
\hline \multirow[t]{8}{*}{ Trial 2} & EC-1.5 & $78.74 \pm 7.4 b$ & $76.44 \pm 1.7 \mathrm{~b}$ & $68.86 \pm 8.5$ \\
\hline & EC-3.5 & $78.22 \pm 5.2 b$ & $75.36 \pm 6.9 \mathrm{~b}$ & $77.02 \pm 7.0$ \\
\hline & EC-5.5 & $88.49 \pm 2.1 \mathrm{a}$ & $82.88 \pm 7.9 \mathrm{ab}$ & $81.04 \pm 5.4$ \\
\hline & EC-7.5 & $93.96 \pm 5.8 \mathrm{a}$ & $86.93 \pm 6.6 \mathrm{ab}$ & $76.57 \pm 3.8$ \\
\hline & EC-9.5 & $86.74 \pm 2.7 \mathrm{ab}$ & $94.80 \pm 8.2 \mathrm{a}$ & $83.43 \pm 7.9$ \\
\hline & ANOVA $^{z}$ & $* *$ & $*$ & NS \\
\hline & Welch-F ${ }^{y}$ & NA & NA & NA \\
\hline & Regression $^{\mathrm{x}}$ & $\mathrm{L}^{*}$ & $\mathrm{~L} * * *$ & $\mathrm{~L}^{*}$ \\
\hline
\end{tabular}

z21Analysis of variance (ANOVA) data are the means \pm SD of three plants. Means for groups in homogeneous subsets are followed by the same letter as reported by Duncan's multiple range test. 'Homogeneity of variances determined by Levene's test; if significant $(P \leq 0.05)$, the Welch $F$ test was used to determine significance.

${ }^{\mathrm{x}} \mathrm{L}$ and $\mathrm{Q}=$ linear and quadratic regression models, respectively. $\mathrm{NS}=$ nonsignificant; $*{ }^{* *}$, and $* * *$ represent significance at $0.05,0.01$, and 0.001 levels, respectively. $\mathrm{NA}=$ not applicable. 
suggests variability when contrasting species and between trials without an obvious trend (Table 5). Table 6 shows the 16 -d postharvest (16DPH) TP and is limited to D. tenuifolia; only $D$. tenuifolia TP significantly responded to treatments and exhibited a consistent declining trend when contrasting the two trials.

Ascorbic acid. For all species collectively evaluated, we observed a response in AsA at harvest to salinity treatments during both trials $(P \leq 0.05$; Table 3$)$. Species did have a significant effect on AsA. Only in Trial 1 was there a significant interaction between treatments and species on AsA. Table 7 shows the variability in AsA responses at harvest to treatments with the most consistent trend a decline

in AsA in response to treatments. The AsA responses $8 \mathrm{DPH}$ predominantly exhibited declines in response to increasing salinity (Table 8). Only in D. tenuifolia did AsA significantly respond to treatments (Table 6).

\section{Discussion}

Total phenolics. The response in TP at harvest to salinity treatments in the specific crucifers evaluated was characterized by variability (i.e., we observed both increases and decreases within the range of treatments we used). The variability in the response of TP to salinity within a species and between trials was unexpected; however, the literature sup-

Table 5. Analysis of variance and regression analysis of 8-d postharvest (8DPH) total phenolic (TP) responses to five salinity treatments in three crucifers in two trials.

\begin{tabular}{|c|c|c|c|c|}
\hline \multirow{2}{*}{\multicolumn{2}{|c|}{ Treatments }} & \multirow{2}{*}{$\frac{\text { Eruca sativa }}{\mathrm{TP}}$} & \multirow{2}{*}{$\frac{\text { Diplotaxis tenuifolia }}{\mathrm{TP}}$} & \multirow{2}{*}{$\frac{\text { Lepidium sativum }}{\mathrm{TP}}$} \\
\hline & & & & \\
\hline \multirow[t]{8}{*}{ Trial 1} & EC-1.5 & $98.26 \pm 23.2$ & $93.91 \pm 2.5 \mathrm{a}$ & $83.81 \pm 13.9 \mathrm{~b}$ \\
\hline & EC-3.5 & $112.29 \pm 16.2$ & $94.29 \pm 5.5 \mathrm{a}$ & $104.12 \pm 7.1 \mathrm{a}$ \\
\hline & EC-5.5 & $101.82 \pm 9.9$ & $84.26 \pm 1.8 \mathrm{a}$ & $78.62 \pm 5.7 b$ \\
\hline & EC-7.5 & $104.33 \pm 21.8$ & $78.49 \pm 9.7 b$ & $89.96 \pm 5.9 \mathrm{ab}$ \\
\hline & EC-9.5 & $90.38 \pm 10.8$ & $78.70 \pm 2.9 b$ & $81.79 \pm 11.6 b$ \\
\hline & $\mathrm{ANOVA}^{\mathrm{z}}$ & NS & $* * *$ & $*$ \\
\hline & Welch-F ${ }^{y}$ & NA & $*$ & NA \\
\hline & Regression $^{\mathrm{x}}$ & NS & $\mathrm{L} * * *$ & NS \\
\hline \multirow[t]{8}{*}{ Trial 2} & EC-1.5 & $86.66 \pm 5.5 b$ & $113.67 \pm 7.7 \mathrm{a}$ & $87.31 \pm 3.9 \mathrm{c}$ \\
\hline & EC-3.5 & $124.93 \pm 14.3 \mathrm{a}$ & $113.42 \pm 8.5 \mathrm{a}$ & $110.18 \pm 6.1 \mathrm{a}$ \\
\hline & EC-5.5 & $103.01 \pm 4.5 \mathrm{ab}$ & $104.00 \pm 1.1 \mathrm{ab}$ & $85.78 \pm 1.0 \mathrm{c}$ \\
\hline & EC-7.5 & $108.37 \pm 17.1 \mathrm{ab}$ & $94.42 \pm 6.8 b$ & $96.46 \pm 3.9 b$ \\
\hline & EC-9.5 & $120.56 \pm 34.1 \mathrm{ab}$ & $110.33 \pm 3.7 \mathrm{a}$ & $107.64 \pm 1.8 \mathrm{a}$ \\
\hline & ANOVA $^{z}$ & NS & $*$ & $* * *$ \\
\hline & Welch-Fy & $*$ & NA & NA \\
\hline & Regression $^{\mathrm{x}}$ & NS & NS & NS \\
\hline
\end{tabular}

${ }^{2}$ Analysis of variance (ANOVA) data are the means \pm SD of three plants. Means for groups in homogeneous subsets are followed by the same letter as reported by Duncan's multiple range test.

${ }^{\text {y} H o m o g e n e i t y ~ o f ~ v a r i a n c e s ~ d e t e r m i n e d ~ b y ~ L e v e n e ' s ~ t e s t ; ~ i f ~ s i g n i f i c a n t ~}(P \leq 0.05)$, the Welch $F$ test was used to determine significance.

${ }^{\mathrm{x}} \mathrm{L}$ and $\mathrm{Q}=$ linear and quadratic regression models, respectively.

NS $=$ nonsignificant; $* * *$, and $* *$ represent significance at $0.05,0.01$, and 0.001 levels, respectively. $\mathrm{NA}=$ not applicable.

Table 6. ANOVA and regression analysis of the 16-d postharvest (16DPH) total phenolics (TP) and ascorbic acid (AsA) responses to five nutrient solution salinities in Diplotaxis tenuifolia.

\begin{tabular}{|c|c|c|c|}
\hline \multirow[b]{2}{*}{ Treatments } & & Diplotaxis tenuifolia & Diplotaxis tenuifolia \\
\hline & & TP & AsA \\
\hline \multirow[t]{8}{*}{ Trial 1} & EC-1.5 & $117.97 \pm 8.9 \mathrm{ab}$ & $69.90 \pm 2.2 \mathrm{a}$ \\
\hline & EC-3.5 & $123.72 \pm 7.2 \mathrm{a}$ & $62.81 \pm 5.1 \mathrm{ab}$ \\
\hline & EC-5.5 & $100.24 \pm 9.0 \mathrm{~cd}$ & $67.67 \pm 4.1 \mathrm{a}$ \\
\hline & EC-7.5 & $105.78 \pm 7.8 \mathrm{abc}$ & $59.26 \pm 10.3 b$ \\
\hline & EC-9.5 & $89.79 \pm 5.2 \mathrm{~d}$ & $54.69 \pm 3.6 \mathrm{~b}$ \\
\hline & ANOVA $^{z}$ & ** & $*$ \\
\hline & Welch-Fy & NA & NA \\
\hline & Regression $^{\mathrm{x}}$ & $\mathrm{L}^{* * *}$ & $\mathrm{~L}^{* *}$ \\
\hline \multirow[t]{8}{*}{ Trial 2} & EC-1.5 & $110.86 \pm 6.4 \mathrm{ab}$ & $99.50 \pm 2.3 \mathrm{a}$ \\
\hline & EC-3.5 & $100.40 \pm 10.6 \mathrm{bc}$ & $74.63 \pm 11.9 \mathrm{bc}$ \\
\hline & EC-5.5 & $118.54 \pm 9.0 \mathrm{a}$ & $94.52 \pm 2.2 \mathrm{ab}$ \\
\hline & EC-7.5 & $97.90 \pm 7.2 \mathrm{bc}$ & $70.89 \pm 11.3 \mathrm{c}$ \\
\hline & EC-9.5 & $87.86 \pm 1.9 c$ & $58.92 \pm 6.8 \mathrm{c}$ \\
\hline & ANOVA $^{z}$ & ** & $* * *$ \\
\hline & Welch-Fy & NA & ** \\
\hline & Regression $^{x}$ & $\mathrm{Q}^{*}$ & $\mathrm{~L} * *$ \\
\hline
\end{tabular}

${ }^{\mathrm{z}}$ Analysis of variance (ANOVA) data are the means \pm SD of three plants. Means for groups in homogeneous subsets are followed by the same letter as reported by Duncan's multiple range test.

${ }^{y}$ Homogeneity of variances determined by Levene's test; if significant $(P \leq 0.05)$, the Welch $F$ test was used to determine significance.

${ }^{\mathrm{x}} \mathrm{L}$ and $\mathrm{Q}=$ linear and quadratic regression models, respectively.

$*, * *$, and $* * *$ represent significance at $0.05,0.01$, and 0.001 levels, respectively.

$\mathrm{NA}=$ not applicable. ports the premise that plants have unique and differential responses to stress (Bergquist et al., 2007b; Di Venere et al., 2000; Heimler et al., 2006).

A simple answer to the observation of variability in the TP responses to treatments between trials is not obvious given that our greenhouse climate data revealed a $1^{\circ}$ degree increase $\left(22.3\right.$ to $23.1{ }^{\circ} \mathrm{C}$ ) in mean daily temperatures (Table 2). Mean relative humidity, however, increased significantly during Trial 2 by $32 \%$ and $50 \%$, during the day and night, respectively (Table 2). The average daily solar radiation values were similar between trials; however, higher peak illumination periods (i.e., higher $P A R$ values) were observed in Trial 1. Based on those modest climate differences between trials and a literature review, we have three hypotheses that address the differences between trials. The first hypothesis addresses the modest overall climate differences, the second considers peak periods of illumination, and the third focuses on the increase in humidity during Trial 2.

Not anticipating meaningful differences in overall climate between trials and to maintain consistency between trials, harvests dates were scheduled on the number of days after treatments began rather than on a physical attribute such as the length of the longest leaf for each replicate. The modest overall climate differences may have been sufficient to alter ontological development in one or more of the species with a putative resultant change in phenolic accumulation at harvest. A literature review provides support for the premise that secondary metabolite (e.g., phenolics) variation occurs at multiple levels: between ontological stages and in response to biotic and abiotic factors (Bergquist et al., 2005, 2007b; Tattini et al., 2004). Furthermore, interspecific variation in plant polyphenols is the expected rather than the exception (Hättenschwiler and Vitousek, 2000); and given that our species have unique character traits, differential responses should have been anticipated as a result of the modest climate differences we observed during the separate trials. E. sativa and L. sativum are mesomorphic annuals characterized by the $\mathrm{C}_{3}$ photosynthetic pathway, whereas $D$. tenuifolia is a $\mathrm{C}_{3}-\mathrm{C}_{4}$ intermediate (Ueno et al., 2003). Our results with field-grown arugula (Hamilton, 2010) indicated that D. tenuifolia survives summers in the semiarid Sonoran Desert without supplemental water, whereas $E$. sativa can persist only if early summer monsoon rains occur. Our field experience with L. sativum is that it survives in our region only with supplemental irrigation; it is the first in a greenhouse to exhibit a "visual" loss of leaf turgor when water-stressed. Studies with E. sativa and L. sativum germinated in municipal wastes, inclusive of EC $7.5 \mathrm{dS} \cdot \mathrm{m}^{-1}$, suggest they have similar salinity tolerances. Germination in D. tenuifolia declines between EC 8.0 and $12.0 \mathrm{dS} \cdot \mathrm{m}^{-1}$ and its salinity tolerance is inferred from endemic and naturalized habitats (Martínez-Laborde, 1997). Given that an increase in phenolics occurs in response to 
Table 7. ANOVA and regression analysis of the at harvest ascorbic acid (AsA) content responses to five nutrient solution salinities in three crucifers during two trials.

\begin{tabular}{|c|c|c|c|c|}
\hline \multirow{2}{*}{\multicolumn{2}{|c|}{ Treatments }} & Eruca sativa & Diplotaxis tenuifolia & Lepidium sativum \\
\hline & & AsA & AsA & AsA \\
\hline \multirow[t]{8}{*}{ Trial 1} & EC-1.5 & $124.38 \pm 19.8 \mathrm{a}$ & $92.77 \pm 8.3$ & $103.21 \pm 7.8 \mathrm{a}$ \\
\hline & EC-3.5 & $102.12 \pm 10.4 \mathrm{ab}$ & $79.81 \pm 22.9$ & $78.99 \pm 11.5 \mathrm{~b}$ \\
\hline & EC-5.5 & $79.47 \pm 4.4 \mathrm{~b}$ & $79.84 \pm 17.7$ & $62.90 \pm 13.0 \mathrm{bc}$ \\
\hline & EC-7.5 & $100.81 \pm 18.6 \mathrm{ab}$ & $94.66 \pm 19.6$ & $67.46 \pm 5.9 \mathrm{bc}$ \\
\hline & EC-9.5 & $87.72 \pm 20.2 \mathrm{~b}$ & $105.94 \pm 13.9$ & $57.85 \pm 4.8 \mathrm{c}$ \\
\hline & ANOVA $^{z}$ & $*$ & NS & $* * *$ \\
\hline & Welch-Fy & NA & NA & NA \\
\hline & Regression $^{\mathrm{x}}$ & $\mathrm{Q}^{*}$ & NS & $\mathrm{Q}^{* * *}$ \\
\hline \multirow[t]{8}{*}{ Trial 2} & EC-1.5 & $118.50 \pm 4.1 \mathrm{ab}$ & $147.95 \pm 19.8$ & $125.69 \pm 7.9 \mathrm{a}$ \\
\hline & EC-3.5 & $150.56 \pm 25.5 \mathrm{a}$ & $193.57 \pm 45.4$ & $121.76 \pm 14.2 \mathrm{a}$ \\
\hline & EC-5.5 & $129.61 \pm 23.9 \mathrm{ab}$ & $174.13 \pm 4.5$ & $101.46 \pm 15.0 \mathrm{~b}$ \\
\hline & EC-7.5 & $100.80 \pm 6.0 \mathrm{~b}$ & $149.25 \pm 27.5$ & $86.93 \pm 4.7 b$ \\
\hline & EC-9.5 & $124.64 \pm 15.5 \mathrm{ab}$ & $129.61 \pm 14.2$ & $92.96 \pm 8.2 b$ \\
\hline & ANOVA $^{z}$ & * & NS & $* *$ \\
\hline & Welch-Fy & NS & NS & NA \\
\hline & Regression $^{\mathrm{x}}$ & NS & $\mathrm{Q}^{*}$ & $\mathrm{~L}^{* * *}$ \\
\hline
\end{tabular}

${ }^{\mathrm{z}}$ Analysis of variance (ANOVA) data are the means \pm SD of three plants. Means for groups in homogeneous subsets are followed by the same letter as reported by Duncan's multiple range test.

${ }^{y}$ Homogeneity of variances determined by Levene's test; if significant $(P \leq 0.05)$, the Welch $F$ test was used to determine significance.

${ }^{\mathrm{x}} \mathrm{L}$ and $\mathrm{Q}=$ linear and quadratic regression models, respectively.

NS $=$ nonsignificant; $*, * *$, and $* * *$ represent significance at $0.05,0.01$, and 0.001 levels, respectively.

$\mathrm{NA}=$ not applicable.

Table 8. ANOVA and regression analysis of the 8 days postharvest (8DPH) ascorbic acid (AsA) content responses to five nutrient solution salinities in crucifers during Trials 1 and 2.

\begin{tabular}{|c|c|c|c|c|}
\hline \multirow{2}{*}{\multicolumn{2}{|c|}{ Treatments }} & Eruca sativa & Diplotaxis tenuifolia & Lepidium sativum \\
\hline & & AsA & AsA & AsA \\
\hline \multirow[t]{8}{*}{ Trial 1} & EC-1.5 & $85.63 \pm 1.4 \mathrm{a}$ & $74.63 \pm 17.1$ & $99.34 \pm 2.4 \mathrm{a}$ \\
\hline & EC-3.5 & $88.85 \pm 11.1 \mathrm{a}$ & $71.25 \pm 20.6$ & $73.36 \pm 6.6 b$ \\
\hline & EC-5.5 & $64.16 \pm 12.6 \mathrm{~b}$ & $72.01 \pm 6.4$ & $48.76 \pm 10.5 \mathrm{c}$ \\
\hline & EC-7.5 & $88.73 \pm 5.4 \mathrm{a}$ & $84.58 \pm 5.5$ & $43.72 \pm 10.6 \mathrm{c}$ \\
\hline & EC-9.5 & $68.87 \pm 5.5 \mathrm{~b}$ & $67.56 \pm 12.2$ & $50.18 \pm 7.1 \mathrm{c}$ \\
\hline & ANOVA $^{z}$ & * & NS & $* * *$ \\
\hline & Welch-F ${ }^{y}$ & $*$ & NA & NA \\
\hline & Regression $^{\mathrm{x}}$ & NS & NS & $\mathrm{Q}^{* * *}$ \\
\hline \multirow[t]{8}{*}{ Trial 2} & EC-1.5 & $85.10 \pm 6.0 \mathrm{~b}$ & $128.57 \pm 22.6$ & $53.68 \pm 4.5 \mathrm{bc}$ \\
\hline & EC-3.5 & $129.62 \pm 25.6 \mathrm{a}$ & $169.04 \pm 54.7$ & $88.42 \pm 17.7 \mathrm{a}$ \\
\hline & EC-5.5 & $109.16 \pm 15.4 \mathrm{ab}$ & $164.97 \pm 20.4$ & $68.08 \pm 4.5 b$ \\
\hline & EC-7.5 & $91.50 \pm 15.5 \mathrm{~b}$ & $115.21 \pm 2.3$ & $40.59 \pm 1.1 \mathrm{~cd}$ \\
\hline & EC-9.5 & $107.36 \pm 13.8 \mathrm{ab}$ & $107.36 \pm 24.9$ & $36.66 \pm 2.3 \mathrm{~d}$ \\
\hline & ANOVA $^{z}$ & $*$ & NS & $* * *$ \\
\hline & Welch-Fy & * & NS & NA \\
\hline & Regression $^{\mathrm{x}}$ & NS & NS & $\mathrm{Q}^{* *}$ \\
\hline
\end{tabular}

${ }^{\mathrm{z}}$ Analysis of variance (ANOVA) data are the means \pm SD of three plants. Means for groups in homogeneous subsets are followed by the same letter as reported by Duncan's multiple range test.

${ }^{\mathrm{y}} \mathrm{Homogeneity}$ of variances determined by Levene's test; if significant $(P \leq 0.05)$, the Welch $F$ test was used to determine significance.

${ }^{\mathrm{x}} \mathrm{L}$ and $\mathrm{Q}=$ linear and quadratic regression models, respectively.

$\mathrm{NS}=$ nonsignificant; $*{ }^{* *}$, and $* * *$ represent significance at $0.05,0.01$, and 0.001 levels, respectively. $\mathrm{NA}=$ not applicable.

moderate water stress, with a differential effect on specific classes of phenolics to that moderate stress (Kouki and Manetas, 2002), our hypothesis for the inconsistencies between trials is that plant-specific responses (e.g., the production of different phenolics) occurred in response to the modest climate differences and in response to each increasing level of salinity treatment.

Another possible explanation for the variation in phenolic content between trials is related to the higher peak illumination periods observed in Trial 1. The influence of intermittent bright sun flecks can induce oxidative stress at the leaf level, resulting in high TP of shade-adapted leaves (Watling et al., 1997). The position of the shadecloth in our greenhouse was constant; however, as a result of seasonal effects, the angle that light entered the greenhouse was lower during the first trial. Although peak periods of illumination were based on quantitative values, the transient periods of direct sunlight on specific plots was simply an observation. A hypothesis that a seemingly minor flux in an abiotic factor (i.e., transient sunlight flecks) may have a quantifiable biologically relevant influence is supported by the literature (Watling et al., 1997).

The simplest hypothesis centers on the observed increase in relative humidity $(\mathrm{RH})$ dur- ing Trial 2. We reported that the average $\mathrm{RH}$ increased from Trial 1 to Trial 2 by $32 \%$ (day) and 50\% (night), respectively (Table 2). A review of the literature that addresses the relationship between $\mathrm{RH}$ and salinity suggests that the modest differences in $\mathrm{RH}$ that we observed can have biologically relevant consequence. For example, in the highly salt-sensitive red kidney bean (Phaseolus vulgaris $\mathrm{L}$.), grown in $\mathrm{NaCl}$ solutions ranging from 0 to $9800 \mathrm{ppm}$ (EC 0.0 to greater than $\left.15.0 \mathrm{dS} \cdot \mathrm{m}^{-1}\right)$, it was demonstrated that at a continuous $95 \% \mathrm{RH}$, although plant size was declined, fruit yield was maintained (O’Leary, 1975). Subsequent studies suggest that, depending on the salt sensitivity of the species, increases in RH (e.g., from $30 \%$ to $70 \% \mathrm{RH}$ ) can improve yields when plants are subjected to moderate (EC.5.0 $\mathrm{dS} \cdot \mathrm{m}^{-1}$ ) or high (EC greater than $\left.9.0 \mathrm{dS} \cdot \mathrm{m}^{-1}\right)$ salinities in the nutrient solution (An et al., 2005).

Thus, we hypothesize that the dissimilar response of harvest TP to salinity treatments between our two trials is attributable to a synergistic effect between the observed modest changes in climatic factors coupled with known species-specific responses. Although admittedly tenuous, the differential pattern of light exposure between trials, the significant difference in humidity, in conjunction with the factors reviewed here to account for within-trial variation may suggest a rationale for the variation between trials.

Ascorbic acid. Although referenced by multiple names, vitamin $\mathrm{C}$, ascorbate, L-ascorbic acid, or just ascorbic acid, this antioxidant is the most abundant antioxidant in plants (Smirnoff, 2000). Within the literature, vitamin C usually references both AsA and oxidation product dehydroascorbic acid (DHA) with AsA at harvest being the predominant form (Davey et al., 2000). The DCPIP assay we used is an accepted proxy for vitamin $\mathrm{C}$ content in that DCPIP is reduced by AsA in 1:1 ratio; thus, it does not account for DHA (AOAC, 1990). Modest variations in the DHA/AsA ratio are reported to be associated with both pre- and postharvest factors (Bergquist et al., 2007a; Gil et al., 1999). In the following discussion, the antioxidant in question will be referenced as AsA or vitamin C depending on how it was used in the supporting literature.

Vitamin $\mathrm{C}$ and AsA content variations are reported in leafy vegetables by: species (Heimler et al., 2006; Martínez-Sánchez et al., 2008; Podsedek, 2007), growth stage, harvest date, shading (Bergquist et al., 2005, 2007a, $2007 \mathrm{~b}$ ) in response to time of day, season, and stress (Davey et al., 2000; Navarro et al., 2006) in response to postharvest storage conditions (Bergquist et al., 2007a; Gil et al., 1999; Mahmud et al., 1999) and quantitatively by the method of assay (Martínez-Sánchez et al., 2008). The reported vitamin C or AsA content of crucifers in general (Podsedek, 2007) and D. tenuifolia and E. sativa specifically (Martínez-Sánchez et al., 2008) is consistent with values we observed in our specific crucifers (Table 7) as are the range of AsA values reported for other cruciferous vegetables (Davey et al., 2000). Our results are 
consistent with other research in that at harvest, $D$. tenuifolia AsA values may be greater than E. sativa; however, our highest values were from $20 \%$ to $50 \%$ greater when contrasted to one study (Martínez-Sánchez et al., 2008). In two related studies that were focused on D. tenuifolia, our harvest AsA values were similar to one study (MartínezSánchez et al., 2006a) yet over 50\% greater than the other study (Martínez-Sánchez et al., 2006b). The differences in our results in contrast to the results reported by MartínezSánchez et al. (2006b) highlights the variable range of antioxidant content observed within a species.

Two important abiotic factors differentiate the referenced studies to ours; our study included salinity treatments in a CE atmosphere system, whereas the referenced studies were conducted under field conditions during the winter with unspecified cultivation practices. The postharvest decline of vitamin $\mathrm{C}$ in D. tenuifolia under controlled conditions in those studies (Martínez-Sánchez et al., 2006a, 2006b) reflects what we observed for our crucifers with a difference being that they distinguished between AsA and DHA but did not include salinity. The postharvest decline in AsA content that we typically observed in our highest salinity treatments was similarly reported for B. rapa; however, B. rapa AsA was reported to recover during the 7DPH to 14DPH period (Mahmud et al., 1999). The postharvest decline that we observed in AsA values from harvest to $16 \mathrm{DPH}$ (Table 6) is similar to that reported for $S$. oleracea (Bergquist et al., 2006, 2007a). Contrasting our postharvest results with others is complicated by the fact that we attempted to emulate extreme postharvest storage conditions, $12{ }^{\circ} \mathrm{C}$, rather than 2 to $4{ }^{\circ} \mathrm{C}$. A study that contrasted postharvest changes in vitamin $\mathrm{C}$ in $\mathrm{S}$. oleracea as a function of preharvest conditions, light transmittance, and postharvest temperature ( 2 and $10{ }^{\circ} \mathrm{C}$ ) did report results for their low light transmittance treatment with a postharvest storage temperature of $10{ }^{\circ} \mathrm{C}$, which are very similar to our $12{ }^{\circ} \mathrm{C}$ postharvest results (Bergquist et al., 2007a).

The variations in AsA levels that we observed within a species, between trials, and during postharvest storage are consistent with the biologically variable nature of this essential dietary antioxidant (Davey et al., 2000; Smirnoff, 2000). The variations in AsA content we observed between trials are similar to those reported for D. tenuifolia (MartínezSánchez et al., 2006a, 2006b) and for other leaf greens (Bergquist et al., 2006, 2007a). That the variations in AsA in response to salinity in a specific trial for a specific species was best depicted by a higher-order regression model (Tables 7 and 8) has some support in the literature. Linear models are considered limited representatives of biological phenomena in general (Segel, 1980). Salinity may impede ontological development (Hasegawa et al., 2000) and defensive plant compounds are reported to be differentially expressed at a specific ontogenetic stage (Bergquist et al., 2005); collectively taken this suggests that a nonlinear response in antioxidants to salinity stress should be expected.

\section{Summary and Conclusion}

The focus of our research was to investigate the effects of nutrient solution salinity (EC 1.5 to $9.5 \mathrm{dS} \cdot \mathrm{m}^{-1}$ ) on AsA and TP in three cruciferous leafy vegetables, $D$. tenuifolia, E. sativa, and L. sativum, using an EFI recycling system in a CE. We observed that harvest nutritional content of the three crucifers evaluated is consistent with what has been previously reported. The results in our study revealed that with moderately high levels of salinity (EC 5.5 to $9.5 \mathrm{dS} \cdot \mathrm{m}^{-1}$ ), both AsA and TP respond to increasing salinity, yet that response was highly variable between species and trials both at harvest and during postharvest periods. Our initial assumption that microclimatic conditions (e.g., light, temperature, humidity) between our two trials would be constant was incorrect; maximum peak solar radiation and $\mathrm{RH}$ did differ between trials. Changing microclimate conditions are suggested as a possible source of the variability we observed when contrasting the individual crucifers' response to increasing salinity. Thus, even with the climate control potentially afforded by a CE, the determination of an ideal nutrient solution salinity level that enhances the nutritional quality of leafy vegetables may be dependent on subtle environmental influences. In addition, our research suggests that salinity levels greater that an EC of $9.5 \mathrm{dS} \cdot \mathrm{m}^{-1}$ may be required to define the salinity tolerance of these specific crucifers within a $\mathrm{CE}$ using an EFI system.

Given the limited information available concerning the specific effects of a range of salinity treatments on the nutritional status of our selected crucifers, in association with the upward trend in CE production in arid regions, our research should have value for producers and consumers.

\section{Literature Cited}

Albrecht, J.A. and H.W. Schafer. 1990. Comparison of two methods of ascorbic acid determination in vegetables. J. Liq. Chromatogr. 13: 2633-2641.

An, P., S. Inanaga, X.J. Li, A.E. Eneji, and N.W. Zhu. 2005. Interactive effects of salinity and air humidity on two tomato cultivars differing in salt tolerance. J. Plant Nutr. 28:459-473.

AOAC. 1990. Vitamin C (ascorbic acid) in vitamin preparations and juices: 2,6-Dichlorindophenol titrimetric method, p. 1058-1059. Cuniff, P. (ed.). Official methods of analysis of AOAC International. AOAC, Arlington, VA.

Ashraf, M. and T. McNeilly. 2004. Salinity tolerance in brassica oilseeds. Crit. Rev. Plant Sci. 23:157-174.

Bachmann, J. 2002. Specialty vegetables, p. 1-7. In: ATTRA (ed.). National Center for Appropriate Technology, Butte, MT.

Bennett, R.N., E.A.S. Rosa, F.A. Mellon, and P.A. Kroon. 2006. Ontogenic profiling of glucosinolates, flavonoids, and other secondary metabolites in Eruca sativa (Salad Rocket), Diplotaxis erucoides (Wall Rocket), Diplotaxis tenuifolia (Wild Rocket), and Bunias orientalis
(Turkish Rocket). J. Agr. Food Chem. 54: 4005-4015.

Bergquist, S.Å.M., U.E. Gertsson, P. Knuthsen, and M.E. Olsson. 2005. Flavonoids in baby spinach (Spinacia oleracea L.): Changes during plant growth and storage. J. Agr. Food Chem. 53:9459-9464.

Bergquist, S.Å.M., U.E. Gertsson, L.Y. Nordmark, and M.E. Olsson. 2007a. Ascorbic acid, carotenoids, and visual quality of baby spinach as affected by shade netting and postharvest storage. J. Agr. Food Chem. 55:8444-8451.

Bergquist, S.A.M., U.E. Gertsson, L.Y.G. Nordmark, and M.E. Olsson. 2007b. Effects of shade nettings, sowing time and storage on baby spinach flavonoids. J. Sci. Food Agr. 87:2464-2471.

Bergquist, S.Å.M., U.E. Gertsson, and M.E. Olsson. 2006. Influence of growth stage and postharvest storage on ascorbic acid and carotenoid content and visual quality of baby spinach (Spinacia oleracea L.). J. Sci. Food Agr. 86:346-355.

Davey, M.W., M.V. Montagu, D. Inze, M. Sanmartin, A. Kanellis, N. Smirnoff, I.J. Benzie, J.J. Strain, D. Favell, and J. Fletcher. 2000. Plant L-ascorbic acid: Chemistry, function, metabolism, bioavailability and effects of processing. J. Sci. Food Agr. $80: 825-860$.

Di Venere, D., N. Calabrese, V. Linsalata, A Cardinali, and V.V. Bianco. 2000. Influence of sowing time on phenolic composition of Rocket. Acta Hort. 533:361-364.

Fonseca, J.M., H.-J. Kim, W.L. Kline, C.A. Wyenandt, M. Hoque, H. Ajwa, and N. French. 2009. Effect of preharvest application of a second-generation harpin protein on microbial quality, antioxidants, and shelf life of fresh-cut lettuce. J. Amer. Soc. Hort. Sci. 134:141-147.

Gil, M.I., F. Ferreres, and F.A. Tomas-Barberan 1999. Effect of postharvest storage and processing on the antioxidant constituents (flavonoids and vitamin C) of fresh-cut spinach. J. Agr. Food Chem. 47:2213-2217.

Hamilton, J.M. 2010. Arugula crop production in arid and semi-arid regions: Nutritional value, postharvest quality, and sustainability in controlled environments. PhD diss., University of Arizona, Tucson, AZ.

Hasegawa, P.M., R.A. Bressan, J.-K. Zhu, and H.J. Bohnert. 2000. Plant cellular and molecular responses to high salinity. Annu. Rev. Plant Physiol. Plant Mol. Biol. 51:463-499.

Hättenschwiler, S. and P.M. Vitousek. 2000. The role of polyphenols in terrestrial ecosystem nutrient cycling. Trends Ecol. Evol. 15:238-243.

Heimler, D., P. Vignolini, M.G. Dini, F.F. Vincieri, and A. Romani. 2006. Antiradical activity and polyphenol composition of local Brassicaceae edible varieties. Food Chem. 99:464-469.

Jaafer, H.Z.E., N.B.M. Haris, and A. Rahmat. 2008. Accumulation and partitioning of total phenols in two varieties of Labisia pumila Benth. under manipulation of greenhouse irradiance. Acta Hort. 797:387-392.

Kim, D.-O. and C.Y. Lee. 2004. Comprehensive study on vitamin $\mathrm{C}$ equivalent antioxidant capacity (VCEAC) of various polyphenolics in scavenging a free radical and its structural relationship. Crit. Rev. Food Sci. Nutr. 44:253-273.

Kim, H.J., J.M. Fonseca, J.H. Choi, C. Kubota, and D.Y. Kwon. 2008. Salt in irrigation water affects the nutritional and visual properties of Romaine lettuce (Lactuca sativa L.). J. Agr. Food Chem. 56:3772-3776.

Kouki, M. and Y. Manetas. 2002. Resource availability affects differentially the levels of gallotannins and condensed tannins in Ceratonia siliqua. Biochem. Syst. Ecol. 30:631-639. 
Ksouri, R., W. Megdiche, A. Debez, H. Falleh, C. Grignon, and C. Abdelly. 2007. Salinity effects on polyphenol content and antioxidant activities in leaves of the halophyte Cakile maritima. Plant Physiol. Biochem. 45:244-249.

Mahmud, T., J. Atherton, C. Wright, M. Ramlan, and S. Ahmad. 1999. Pak Choi (Brassica rapa ssp Chinensis L) quality response to pre-harvest salinity and temperature. J. Sci. Food Agr. 79: 1698-1702.

Martínez-Sánchez, A., A. Allende, R.N. Bennett, F. Ferreres, and M.I. Gil. 2006a. Microbial, nutritional and sensory quality of rocket leaves as affected by different sanitizers. Postharvest Biol. Technol. 42:86-97.

Martínez-Sánchez, A., A. Gil-Izquierd, M.I. Gil, and F. Ferreres. 2008. A comparative study of flavonoid compounds, vitamin $\mathrm{C}$, and antioxidant properties of baby leaf brassicaceae species. J. Agr. Food Chem. 56:2330-2340.

Martínez-Sánchez, A., R. Llorach, M.I. Gil, and F. Ferreres. 2007. Identification of new flavonoid glycosides and flavonoid profiles to characterize Rocket leafy salads (Eruca vesicaria and Diplotaxis tenuifolia). J. Agr. Food Chem. 55: 1356-1363.

Martínez-Sánchez, A., A. Marin, R. Llorach, F. Ferreres, and M.I. Gil. 2006b. Controlled atmosphere preserves quality and phytonutrients in wild rocket (Diplotaxis tenuifolia). Postharvest Biol. Technol. 40:26-33.

Martínez-Laborde, J.B. 1997. A brief account of the genus Diplotaxis, p. 13-22. In: Padulosi, S. and D. Pignone (eds.). Rocket: A Mediterranean crop for the world. International Plant Genetic Resource Institute, Rome, Italy.

Navarro, J.M., P. Flores, C. Garrido, and V. Martinez. 2006. Changes in the contents of antioxidant compounds in pepper fruits at different ripening stages, as affected by salinity. Food Chem. 96:66-73.

Nicola, S., J. Hoeberechts, and E. Fontana. 2007. Ebb-and-flow and floating systems to grow leafy vegetables: A review for Rocket, corn salad, garden cress and purslane. Acta Hort. 747:585-593.

Nuez, F. and J.E. Hernández Bermejo. 1994. Neglected horticultural crops, p. 303-332. In:
Hernández Bermejo, J.E. and J. León (eds.). Neglected crops: 1492 from a different perspective. FAO, Rome, Italy.

O'Leary, J. 1975. High humidity overcomes lethal levels of salinity in hydroponically grown saltsensitive plants. Plant Soil 42:717-721.

Podsedek, A. 2007. Natural antioxidants and antioxidant capacity of Brassica vegetables: A review. LWT-Food Sci.Technol. 40:1-11.

Reddy, A.R., K.V. Chaitanya, and M. Vivekanandan. 2004. Drought-induced responses of photosynthesis and antioxidant metabolism in higher plants. J. Plant Physiol. 161:1189-1202.

Rice-Evans, C.A., N.J. Miller, and G. Paganga. 1997. Antioxidant properties of phenolic compounds. Trends Plant Sci. 2:152-159.

Rodriguez, S.A., M.S. Vela Gurovic, M.C. Mulet, and A.P. Murray. 2006. Diplotaxis tenuifolia (L.) DC., a source of a potentially antifungal essential oil containing nitrile. Biochem. Syst. Ecol. 34:353-355.

Rouphael, Y. and G. Colla. 2005. Growth, yield, fruit quality and nutrient uptake of hydroponically cultivated zucchini squash as affected by irrigation systems and growing seasons. Sci. Hort. 105:177-195.

Segel, L.A. 1980. Mathematical models in molecular and cellular biology. Cambridge University Press, Cambridge, UK.

Serio, F., L.D. Gara, S. Caretto, L. Leo, and P. Santamaria. 2004. Influence of an increased $\mathrm{NaCl}$ concentration on yield and quality of cherry tomato grown in posidonia [Posidonia oceanica (L.) Delile]. J. Sci. Food Agr. 84: 1885-1890.

Shalhevet, J. 1994. Using water of marginal quality for crop production: Major issues. Agr. Water Manage. 25:233-269.

Shannon, M.C. and C.M. Grieve. 1999. Tolerance of vegetable crops to salinity. Sci. Hort. 78:5-38.

Singleton, V.L., R. Orthofer, R.M. Lamuela-Raventos, and P. Lester. 1999. Analysis of total phenols and other oxidation substrates and antioxidants by means of Folin-Ciocalteu reagent, p. 152-178. Methods Enzymol. Academic Press, New York, NY.
Smirnoff, N. 2000. Ascorbic acid: Metabolism and function of a multi-facetted molecule. Curr. Opin. Plant Biol. 3:229-235.

Surh, Y.-J. 2003. Cancer chemoprevention with dietary phytochemicals. Nat. Rev. Cancer 3:768-780.

Suslow, T.V. 2004. Oxidation-reduction potential (ORP) for water disinfection monitoring, control, and documentation, p. 1-5. In: ANR (ed.). UCD, Oakland, CA.

Suyama, H., S.E. Benes, P.H. Robinson, S.R. Grattan, C.M. Grieve, and G. Getachew. 2007. Forage yield and quality under irrigation with saline-sodic drainage water: Greenhouse evaluation. Agr. Water Manage. 88: 159-172.

Tassoni, A., M. Franceschetti, and N. Bagni. 2008. Polyamines and salt stress response and tolerance in Arabidopsis thaliana flowers. Plant Physiol. Biochem. 46:607-613.

Tattini, M., C. Galardi, P. Pinelli, R. Massai, D. Remorini, and G. Agati. 2004. Differential accumulation of flavonoids and hydroxycinnamates in leaves of Ligustrum vulgare under excess light and drought stress. New Phytol. 163:547-561.

Ueno, O., S.W. Bang, Y. Wada, A. Kondo, K. Ishihara, Y. Kaneko, and Y. Matsuzawa. 2003. Structural and biochemical dissection of photorespiration in hybrids differing in genome constitution between Diplotaxis tenuifolia (C3C4) and radish (C3). Plant Physiol. 132:15501559.

Waterhouse, A.L. 2005. Determination of total phenolics, p. 463-470. In: Wrolstad, R.E., T.E. Acree, E.A. Decker and M.H. Penner (eds.). Handbook of food analytical chemistry: Pigments, colorants, flavors, texture, and bioactive food components. Wiley-Interscience, Hoboken, NJ.

Watling, J.R., S.A. Robinson, I.E. Woodrow, and C.B. Osmond. 1997. Responses of rainforest understorey plants to excess light during sunflecks. Aust. J. Plant Physiol. 24:17-25.

Winter, C.K. and S.F. Davis. 2007. Are organic foods healthier. CSA News 52:2-13. 